\title{
Public Debt Frontier: A Python Toolkit for Analyzing Public Debt Sustainability
}

\author{
Gonzalo F. de-Córdoba ${ }^{1,+} \mathbb{D}$, Benedetto Molinari ${ }^{1,2, *,+} \mathbb{D}$ and José L. Torres ${ }^{1,+} \mathbb{D}$ \\ 1 Department of Economic Theory and History, Universidad de Málaga, 29016 Málaga, Spain; \\ gonfermar@uma.es (C.F.d.-C.); jtorres@uma.es (J.L.T.) \\ 2 The Rimini Centre for Economic Analysis (RCEA), Riverside, CA 92521, USA \\ * Correspondence: bmolinari@uma.es \\ + These authors contributed equally to this work.
}

Citation: de-Córdoba, G.F.; Molinari, B.; Torres, J.L. Public Debt Frontier: A Python Toolkit for Analyzing Public Debt Sustainability. Sustainability 2021, 13, 13260. https://doi.org/ $10.3390 /$ su132313260

Academic Editors: Marek Durica,

Lucia Svabova, Jaroslav Frnda and Katarina Kramarova

Received: 29 September 2021 Accepted: 18 November 2021 Published: 30 November 2021

Publisher's Note: MDPI stays neutral with regard to jurisdictional claims in published maps and institutional affiliations.

Copyright: (c) 2021 by the authors. Licensee MDPI, Basel, Switzerland. This article is an open access article distributed under the terms and conditions of the Creative Commons Attribution (CC BY) license (https:// creativecommons.org/licenses/by/ $4.0 /)$.

\begin{abstract}
This study proposes a synthetic visual indicator with which to perform debt sustainability analysis using dynamic general equilibrium models. In a single diagram, we summarized the general equilibrium relationships among economic activity, government budget, and the maximum amount of sustainable public debt. Then, we measured sustainability using the distance of actual debt from the model-consistent maximum debt. This indicator can be implemented with any DSGE model; as a backing theory, we used a neoclassical model augmented with endogenous tax revenues, disaggregated public spending, different production technologies for public and private goods, non-atomistic wage setters in public labor (unions), and a fully specified maturity curve for public bonds. We provided an example of its usage using the case of Greece during the last public debt crisis. To perform the numerical analysis, we developed original software, whose advantage is allowing an audience without expertise in DSGE models to perform general equilibrium debt sustainability analyses without requiring an understanding of the technicalities of DSGE models.
\end{abstract}

Keywords: debt sustainability analysis; fiscal policy; endogenous tax revenues; debt-dependent government spending; DSGE models; standalone software; Python

JEL Classification: E13; H61; E62; H63; H81; H30

\section{Introduction}

The last financial and credit crises again highlighted the issue of excessive public debt and its sustainability. Traditionally, the sustainability of public debt is analyzed using empirical (reduced-form) equations in which a set of parameters is taken as given (typically the interest rate, inflation, and the growth rate of real GDP), and sustainability is defined as a condition relating the level of debt with public accounts [1]. The outcome of such empirical debt sustainability analyses (DSAs) indicates how a government should adjust its budget to maintain a sustainable stock of public debt. A reduction in fiscal deficit (or an increase in surplus) to pursue debt sustainability is usually called fiscal consolidation.

Empirical DSAs, e.g., single-equation estimates of fiscal reaction functions, sustainability equations, fiscal vulnerability equations, and policy criteria such as the Maastricht Treaty conditions, have two main drawbacks: First, they provide policy prescriptions as if the only objective of fiscal policy is fiscal consolidation. This may have been reasonable in periods such as the Great Moderation, when developed economies were characterized by moderate cyclical fluctuations and monetary policy was able to stabilize the economic cycle alone. In the words of Blanchard, "[at that time] fiscal policy took a backseat to monetary policy" [2]. Yet, the financial crisis in 2008-2009 returned the anti-cyclical role of fiscal policy to the forefront. Nowadays, fiscal policy is used as a countercyclical tool to stabilize the economy, and this often conflicts with fiscal consolidation, as noted by [3,4]. 
Second, empirical DSAs do not account for the general equilibrium relationships between fiscal tools and macro aggregates (see, among others, [5]. Intuitively, debt sustainability depends on the ratio of public debt over GDP. Therefore, any fiscal policy negatively affecting GDP, even if it effectively reduces debt, has an indeterminate effect on sustainability because it decreases both the numerator and the denominator of the ratio. The negative effect of fiscal consolidation is due to the negative response of economic activity to tax hikes or government spending reductions. If, in the attempt to adjust fiscal imbalances, the government shrinks economic activity, then it ends up causing further issues because of the worsening of fiscal income and because of the reduction in the denominator of the debt-GDP ratio), and it can provide biased results and misleading policy prescriptions [6]. DSGE models, instead, naturally account for all of the direct, indirect, and general equilibrium feedback effects among fiscal policy, economic activity, and debt sustainability. This enhanced representation of the aggregate economy is obtained at the cost of simplicity. In structural models, the relationships amongst GDP, public debt, and government budgeting are expressed in the form of cross-equation restrictions in the state-space representation of the DSGE model solution. There are no explicit analytical relationships such as those available in traditional DSAs; thus, policy prescriptions are less intuitive. The shortcoming is especially penalizing if the audience does not possess the technical expertise for programming and simulating DSGE models. This possibly explains why debt sustainability analyses based on structural models has not become common in empirical DSAs in policy practice.

In this paper, we propose a method to overcome this previous issue. We show that the salient information contained in DSGE models in the intercourse amongst GDP, fiscal policy, and debt sustainability can be represented in a single diagram in which two steadystate ratios from the model solution are depicted: (i) the primary government spending as percentages of GDP, and (ii) the model-consistent corresponding maximum amount of sustainable debt, which is described by the level of the economic activity. Intuitively, once the government determines primary spending, the level of output is endogenously determined by fiscal multipliers; this, in turn, determines tax bases. The government budget is thus closed $\left(T_{t}-G_{t}\right)$, resulting in a deficit (or surplus) that determines the new level of debt. Using this diagram, visual and intuitive criteria of the sustainability of debt can be applied by measuring the distance between the actual level of debt and the maximum level of debt that is sustainable in the long term given the underlying economy. We call this graphical representation the public debt frontier (PDF).

Figure 1 provides an example of the frontier and the associated visual criteria. At point $(E)$, the economy is at equilibrium, but the government is running an excessive deficit given the existing stock of debt. Our analysis suggests that either the government reduces primary spending from $40.3 \%$ to $35.5 \%$, thus regaining sustainability through a fiscal consolidation (point $E_{2}$ ), or asks for a bail-out to reduce the stock of debt by $19 \%$ without incurring spending reductions (point $E_{1}$ ). Note that only in the on-frontier points (orange line) is the government budget balanced-tax revenues exactly cover primary spending plus debt service-and the government can indefinitely roll over the existing stock of debt regardless of its level, thus gaining credibility and financial solidity. All points to the left of the frontier imply excess public saving, and the stock of debt accordingly diminishes over time. All points to the right of the frontier indicate a situation in which the government's financial solvency is in danger and its credibility as a borrower cannot continue indefinitely. Bad news, lasting crises, and delaying recoveries will all create situations in which rolling over will not be possible; eventually, either a default or some bail-out procedure from international authorities should be expected. 


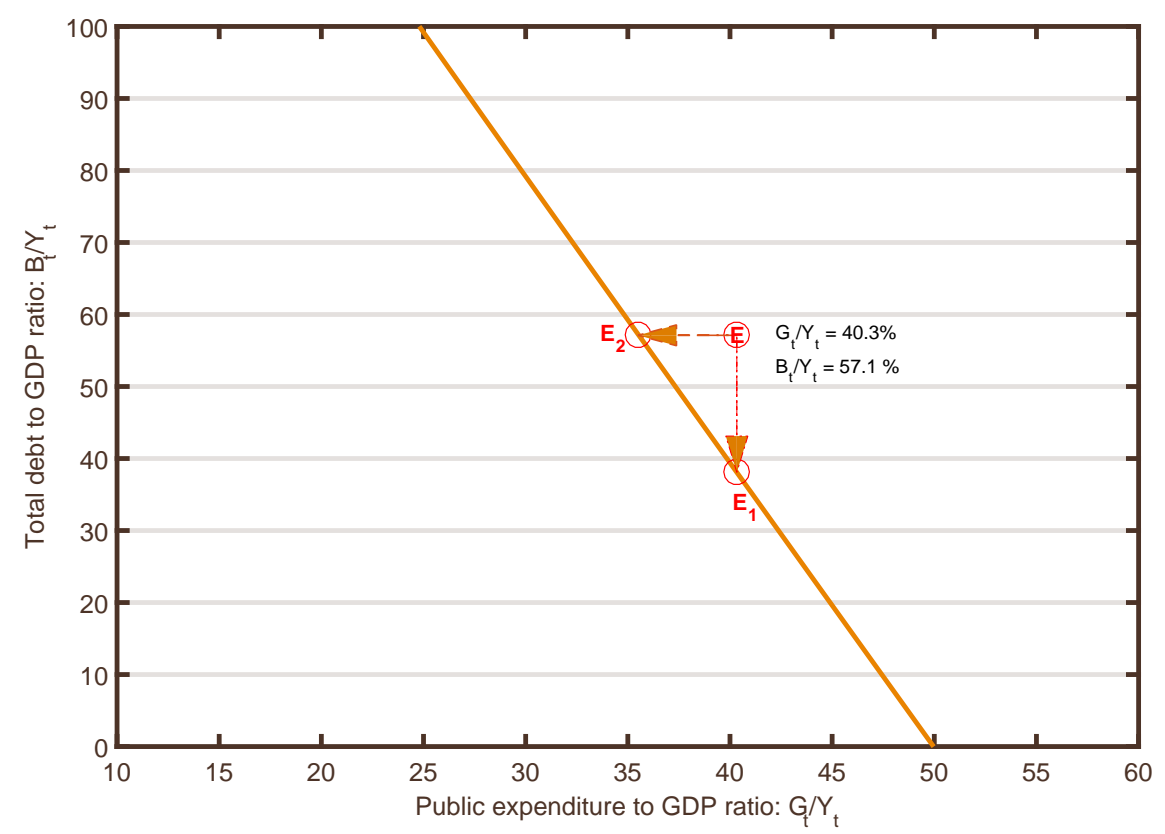

Figure 1. Public debt frontier.

All simulations and the associated graphical analyses presented in this study were performed using an original software that works as a standalone executable for Windows and GNU/Linux. We developed it because the audience interested in managing public debt, or in placing the constraint of debt sustainability on government budgeting decisions, may be different and possibly wider than that possessing the expertise to manage and simulate DSGE models. The software allows them to run fiscal policy experiments without entering into the technicalities of solving for the general equilibrium, computing rational expectations, calibrating steady states, etc. It has has an intuitive user interface requiring only two inputs: (i) the calibration of model parameters to match the economy being considered and (ii) the fiscal policy design. As the output of the analysis, it returns the impact of fiscal shocks on debt sustainability, represented by depicting the pre- and postpolicy public debt frontiers and computing, if needed, the associated fiscal adjustments required to return to a sustainable path.

The rest of the article is organized as follows: Sections 3.1-3.6 present the model, and Sections 3.7 and 3.8 describe its calibration. The construction of the corresponding PDF is explained and depicted in Section 3.9. Section 3.10 presents the toolkit to compute the PDF and its main features. Section 4 provides the quantitative analysis, and Section 5 discusses these results. Finally, Section 6 concludes the article.

\section{Literature Review}

The public debt crisis that followed the financial crisis of 2008-2009 in several European countries raised concerns for the first time about the sustainability of public debt in the EU after the creation of the monetary union and the ECB. This new condition raised the interest of researchers, who especially focused on the relationship between fiscal policy and public debt. From this perspective, a new wave of macro models such as $[7,8]$ has been proposed as alternatives to traditional empirical DSAs. These models account for both the cyclical and consolidation roles of fiscal policy, thus providing a theoretical basis for the usage of DSGE models in public debt sustainability assessments. In this line of research, $\mathrm{Bi}[9]$ analyzed the relationship between sovereign risk premia and the level of government debt using a closed economy DSGE model featuring dynamic Laffer curves. Ko [10] theoretically investigated whether the wealth effect of expansionary fiscal shocks is affected by the debt-to-GDP ratio, and Bi et al. [11] analyzed the stimulative effects of fiscal consolidations when government debt is either high or low and rationalized the 
empirical findings by using a nonlinear neoclassical growth model. In a series of studies, Alesina et al. [12,13] investigated the macroeconomic effects of fiscal consolidations based on government spending cuts, transfers cuts, and tax hikes using DGSE models. Using empirically plausible dynamic general equilibrium models, Wang [14] argued that expansionary policies are conducted at the cost of debt rollover, high interest payments, and heavy taxes, and, therefore, their stimulus effects were analyzed considering a country's initial debt level. Zhang et al. [15] studied the economic impact of the COVID-19 pandemic on the sustainability of Chinese government debt and income inequality using a new Keynesian DSGE model. An estimated small open economy DSGE model was used by Ganbayar [16] to assess the effects of the structural shocks on the external debt sustainability. A two-country open economy DSGE model was used to argue that fiscal consolidation is the least damaging when achieved by reducing the public sector wage bill [17], whereas it is most damaging when carried out by cutting public investment. Finally, Briceño and Perote [18] studied the relative importance of financial, social, governance, and institutional factors in explaining public debt evolution, whereas Domeij and Ellingsen [19] found that the observed level of public debt after the financial crisis is entirely a Ponzi scheme.

From an empirical point of view, Forni et al. [20] simulated a DSGE model of a currency union to assess the macro-economic implications of permanently reducing the public debtto-gross domestic product (GDP) ratio in European area countries, and Ramos-Herrera and Prats [21] estimated both a panel autoregressive distributed lag model and a panel threshold model to analyze long-term fiscal sustainability for a panel of 20 European countries. Fatás and Summers [22] observed that the global financial crisis permanently lowered the path of GDP while raising government debt levels, and they empirically explored the connections between these two findings. Ramos-Herrera and Sosvilla-Rivero [23] acknowledged the paramount importance of fiscal sustainability in the European area countries in the aftermath of the financial crisis of 2008. They focused on the effects of population aging on fiscal sustainability using reduced-form panel data techniques. Using a narrative analysis, Reinhart et al. [24] explored the options for regaining the sustainability of public debt levels relative to nominal GDP in the long term.

Akin to our model, Antosiewicz et al. [25] used a DSGE approach to study the effect of taxes, even though they focused on the effects of environmental taxes on resource use rather than on debt sustainability. Stoian et al. [26] proposed a synthetic indicator of fiscal vulnerability with similar purposes to those developed in this study. Their indicator differs from ours because (i) it uses a cyclically adjusted measure of primary balance, while we use a simple measure; (ii) the distance to stability of public debt is computed using an empirical DSA analysis rather than a DSGE analysis as in this study. The public debt frontier proposed in our study also shares some similarities with the fiscal space of Ghosh et al. [7]. We improve upon their analysis because we used a structural DSGE model as the backing theory instead of a reduced-form model. Yet, they used a more accurate fiscal reaction function with respect to ours, and their interest rate was endogenous and debt-dependent, whereas it was exogenous in our model.

Regarding the original toolkit developed for this study, we are not the first to use Python as programming language to simulate DSGE models. Two remarkable examples are Python Macroeconomics Laboratory (PyMacLab) and QuantEcon.py. The latter is an open source Python code library for economics and finance that is financially supported by the Alfred P. Sloan Foundation and promoted by the Nobel prize winner Thomas J. Sargent. The usage of Dynare running on MATLAB ${ }^{\circledR}$ — the most widespread and commonly used software to compute and simulate DSGE models-still outweighs Python by a factor of 12, according to a Google Scholar search with the terms Python "AND" DSGE (359 results) vs. Dynare “AND” DSGE (4960 results). Nonetheless, the growing success of Python as a programming language suggests that this situation may quickly change. As argued by the PyMacLab team, there are several clear-cut advantages in developing and using software written in Python with respect to any other programming language. First, "Python is rapidly turning itself into the language best supplied with ready-to-use libraries". Second, 
it "glues well into traditional scientific languages", thus allowing existing source codes in other languages (e.g., Fortran and $\mathrm{C}++$ ) to be called inside Python scripts as if they were normal Python routines. Third, differently from Java or G++, Python is interpreted and not compiled thus making "the programming experience much more seamless, interactive and transparent." This turns Python into a rapid application development (RAD) tool.

\section{Materials and Methods}

We developed a general equilibrium model in which the government affects private decisions in a number of ways. We considered distortionary taxation, the consumption of utility-generating goods paid by the government and distributed to households, and public capital and public labor enhancing the aggregate production possibilities. Then, we considered the existence of public debt issued by the government and sold to deep-pocket international investors, thus absorbing domestic resources. Regarding the production side of the economy, firms are represented by a Cobb-Douglas production function requiring four production factors: private and public labor and capital. Firms only pay for private factors, receiving public ones at no cost. This assumption generates nonzero profits that are taxed by the government and, after tax, distributed to households. Finally, households were modeled in a standard method with the only exception of publicly paid consumption goods entering in the utility function and worked hours split between private and public labor. We first describe the modeling of the government, then of firms, and finally of households.

\subsection{The Model: Government}

According to public accounts, government financial flows are, in real terms,

$$
G_{t}+R_{t}^{B} B_{t}+\Delta D_{t}=T_{t}+R_{t}^{D} D_{t}+C B T_{t}+\Delta B_{t}
$$

Equation (1) states that all cash outlays-primary spending $\left(G_{t}\right)$, interest payments $\left(R_{t}^{B} \times B_{t}\right)$, and new purchases of financial assets $\left(\Delta D_{t}\right)$ - must be funded with some combination of tax revenues $\left(T_{t}\right)$, interest earnings on government assets $\left(R_{t}^{D} \times D_{t}\right)$, transfers from the central bank $\left(C B T_{t}\right)$, and new debt issuance $\left(\Delta B_{t}\right)$. For Eurozone countries, transfers from the central bank are zero, and direct purchases of government bonds are precluded by the treaty (i.e., $C B T_{t}=0$ ). We denote by $B_{t}$ the year-on-year net position of the government, so that financial purchases are zero $\left(D_{t}=0\right)$.

Next, we built on [27] by assuming that $G_{t}$ comprises four chapters of spending: government consumption of final goods and services $\left(C_{g, t}\right)$, investment in public capital $\left(I_{g, t}\right)$, public wage bills $\left(W_{g, t} L_{g, t}\right)$, and transfer payments to households $\left(Z_{t}\right)$, such as welfare, social security, or unemployment benefit payments. Analogous to private capital, public investment accrues into a stock of public structures, $K_{g, t}$, which evolves according to a standard accumulation process: $K_{g, t}=\left(1-\delta_{g}\right) K_{g, t-1}+I_{g, t}$, where $\delta_{g}$ is the depreciation rate of public capital. Primary government spending is therefore

$$
G_{t}=C_{g, t}+\left(1+\tau_{t}^{s S}\right) W_{g, t} L_{g, t}+I_{g, t}+Z_{t}
$$

In the analysis, unless otherwise specified, we assumed that each chapter of spending is a constant proportion of primary spending. This split of government's expenditures can be thought of as the result of maximizing a policymaker's preferences of the form $U_{g}\left(C_{g, t}, I_{g, t}, W_{g, t} L_{g, t}, Z_{t}\right)=\log C_{g, t}+\log I_{g, t}+\log L_{g, t}+\log Z_{t}$, subject to the budget constraint given by (2). We denote this proportion with the parameter $\theta$, and accordingly,

$$
\begin{gathered}
C_{g, t}=\theta_{c} G_{t} \\
I_{g, t}=\theta_{i} G_{t} \\
\left(1+\tau_{t}^{s S}\right) W_{g, t} L_{g, t}=\theta_{w l} G_{t} \\
Z_{t}=\theta_{z} G_{t}
\end{gathered}
$$


where $\theta_{c}+\theta_{i}+\theta_{w l}+\theta_{z}=1$.

Regarding fiscal income, we assumed that the government levies four taxes: a consumption tax, a labor income tax, a capital income tax, and a corporate tax, plus a social security tax on the labor input paid by firms. Effective average tax rates are denoted by $\tau_{t}^{c}$, $\tau_{t}^{l}, \tau_{t}^{k}$, and $\tau_{t}^{\pi}$, respectively. The pay-as-you-go social security tax is denoted by $\tau_{t}^{s s}$, and total fiscal income $T_{t}$ is therefore

$$
\begin{aligned}
T_{t}= & \tau_{t}^{c} C_{p, t}+\tau_{t}^{l}\left(W_{p, t} L_{p, t}+W_{g, t} L_{g, t}\right)+\tau_{t}^{k}\left(R_{t}-\delta_{K_{p}}\right) K_{p, t-1} \\
& +\tau_{t}^{\mathcal{S}}\left(W_{p, t} L_{p, t}+W_{g, t} L_{g, t}\right)+\tau_{t}^{\pi} \Pi_{t}
\end{aligned}
$$

where $C_{p, t}$ is private consumption, $W_{p, t}$ is private sector wages, $L_{p, t}$ is private labor, $R_{t}$ is the rental rate of private capital, $\delta_{K_{p}}$ is the depreciation rate of private capital, $K_{p, t}$ is private capital stock, and $\Pi_{t}$ are profits to be defined later.

Combining the elements defined above, the government budget constraint can be now written as

$$
\begin{aligned}
& C_{g, t}+\left(1+\tau_{t}^{s S}\right) W_{g, t} L_{g, t}+I_{g, t}+Z_{t}+\left(1+R_{t}^{B}\right) B_{t} \\
= & \tau_{t}^{c} C_{p, t}+\tau_{t}^{l}\left(W_{p, t} L_{p, t}+W_{g, t} L_{g, t}\right) \\
& +\tau_{t}^{k}\left(R_{t}-\delta_{K_{p}}\right) K_{p, t-1}+\tau_{t}^{S S}\left(W_{p, t} L_{p, t}+W_{g, t} L_{g, t}\right)+\tau_{t}^{\pi} \Pi_{t}+B_{t+1}
\end{aligned}
$$

or, collecting uses and resources,

$$
\begin{aligned}
& C_{g, t}+W_{g, t} L_{g, t}+I_{g, t}+Z_{t}+R_{t}^{B} B_{t}= \\
& \tau_{t}^{c} C_{p, t}+\tau_{t}^{l}\left(W_{p, t} L_{p, t}+W_{g, t} L_{g, t}\right)+\tau_{t}^{k}\left(R_{t}-\delta_{K_{p}}\right) K_{p, t-1}+\tau_{t}^{s S} W_{p, t} L_{p, t}+\tau_{t}^{\pi} \Pi_{t} \\
+ & \left(B_{t+1}-B_{t}\right)
\end{aligned}
$$

with the meaning that all non-financial spending plus servicing of the existing stock of debt must be financed through taxes plus new debt.

\subsection{The Model: Labor Unions}

Our design of the public labor market follows [28], which distorts the labor market to prevent wages' equalization between the private and public sectors. Public wage bills are appreciably different among OECD countries, and government interventions in this area can have large effects on the aggregate dynamics and steady state of the model economy. To provide an objective function replicating government preferences of public employment and wages, we followed a standard textbook approach [29] (on related grounds, Ardagna et al. [30] and Forni et al. [31] considered the wage bill of the government, employment, and wages as arguments of the objective function of the government and public sector unions ), which determines the objective function as the solution of a game between a public-sector union caring about the wages of public-sector employees, $W_{g, t}$, and the government caring about the level of public employment, $L_{g, t}$, given its budget constraints.

The previous setup can be formalized as follows. The government agrees with the union to maximize the objective function

$$
\max \left[\omega W_{g, t}^{\rho}+(1-\omega) L_{g, t}^{\rho}\right]^{1 / \rho}
$$

where $\omega$ is the weight given to wages and $\rho$ is a negative parameter indicating the curvature of the trade-off between the elements present in the objective function of the government. If $\omega$ is close to zero, then the main goal of the government is to maximize public employment (benevolent government preference), whereas if $\omega$ is close to one, the main goal of the government is to maximize public wages (public-sector union's preferred option). Note that Expression (5) encompasses the different approaches found in the literature. On the one hand, it considers the fact that public employment and wages are determined in an 
environment different from the private sector. The government can increase the number of public employees or the public wages subject to the budgetary constraint. On the other hand, it considers the fact that labor unions are more important in the public labor sector than in the private sector [32].

As defined previously, the government wage bill is defined as:

$$
\theta_{3} G_{t}=\left(1+\tau_{t}^{s S}\right) W_{g, t} L_{g, t}
$$

Maximizing the government objective function subject to the government budget constraint involves finding critical values for the auxiliary Lagrangian function:

$$
£_{g}(\cdot)=\max \left[\omega W_{g, t}^{\rho}+(1-\omega) L_{g, t}^{\rho}\right]^{1 / \rho}+\xi\left(\theta_{3} G_{t}-\left(1+\tau_{t}^{S S}\right) W_{g, t} L_{g, t}\right)
$$

This provides, upon differentiation, the necessary first-order conditions:

$$
\begin{aligned}
& \frac{\partial E_{g}(\cdot)}{\partial W_{g, t}}=\left[\omega W_{g, t}^{\rho}+(1-\omega) L_{g, t}^{\rho}\right]^{1 / \rho-1} \omega W_{g, t}^{\rho-1}-\xi\left(1+\tau_{t}^{S S}\right) L_{g, t}=0 \\
& \frac{\partial E_{g}(\cdot)}{\partial L_{g, t}}=\left[\omega W_{g, t}^{\rho}+(1-\omega) L_{g, t}^{\rho}\right]^{1 / \rho-1}(1-\omega) L_{g, t}^{\rho-1}-\xi\left(1+\tau_{t}^{S S}\right) W_{g, t}=0
\end{aligned}
$$

Dividing orderly, we obtain

$$
\omega W_{g, t}^{\rho}=(1-\omega) L_{g, t}^{\rho}
$$

Combining this expression with Equation (6), we find that public wages and employment are equal to:

$$
\begin{gathered}
W_{g, t}=\left(\frac{\omega}{1-\omega}\right)^{-1 / 2 \rho}\left[\frac{\theta_{3} G_{t}}{\left(1+\tau_{t}^{s S}\right)}\right]^{1 / 2} \\
L_{g, t}=\left(\frac{\omega}{1-\omega}\right)^{1 / 2 \rho}\left[\frac{\theta_{3} G_{t}}{\left(1+\tau_{t}^{S S}\right)}\right]^{1 / 2}, \text { if } W_{g, t}>W_{p, t}
\end{gathered}
$$

The distribution of public resources depends on government preferences. However, private and public sectors compete for the same labor input, and, as a consequence, a relationship exists between public-sector and private-sector wages, inducing a wage premium. The wage premium is implicit in Equation (9), and it is part of the solution to the government's problem. This wage premium ensures the government that its demand for labor will always be satisfied. This relationship will become clearer once we present the household problem.

\subsection{The Model: Firms}

The representative firm operates a standard, constant-returns-to-scale, Cobb-Douglas production function. Private and public capital are (imperfect) substitutes, whereas the degree of substitutability between private and public labor is controlled by a CES aggregator. The problem faced by a firm is to find the optimal level of capital and labor services to maximize period profits given the amount of public inputs. Private goods and factors markets are perfectly competitive. The production technology is described by

$$
Y_{t}=A_{t} K_{p, t-1}^{\alpha_{p}} K_{g, t-1}^{\alpha_{g}}\left[\mu L_{p, t}^{\eta}+(1-\mu) L_{g, t}^{\eta}\right]^{\frac{\alpha_{l}}{\eta}}
$$

where $Y_{t}$ is the aggregate output, and $A_{t}$ is the total factor productivity. $K_{p, t-1}$ and $K_{g, t-1}$ are private and public capital services, respectively, and $L_{p, t-1}$ and $L_{g, t-1}$ are private and public labor services, respectively. Parameters $0<\alpha_{p}<1,0<\alpha_{g}<1$, and $0<\alpha_{l}=$ $1-\alpha_{p}-\alpha_{g}<1$ are the private and public capital share of output and labor, respectively; $0<\mu<1$ measures the weight of public employment relative to private employment; and 
$\psi=1 /(1-\eta)$ is a measure of the elasticity of the substitution between public and private labor inputs.

From the firm's profit maximization problem, we obtained the optimal demand of private capital and labor, i.e.,

$$
\begin{gathered}
\left(1+\tau_{t}^{s S}\right) W_{p, t} L_{p, t}=\mu \alpha_{l} A_{t} K_{p, t-1}^{\alpha_{p}} K_{g, t-1}^{\alpha_{g}}\left[\mu L_{p, t}^{\eta}+(1-\mu) L_{g, t}^{\eta}\right]^{\left(\alpha_{l}-\eta\right) / \eta} L_{p, t}^{\eta} \\
=\frac{\mu \alpha_{l} L_{p, t}^{\eta}}{\mu L_{p, t}^{\eta}+(1-\mu) L_{g, t}^{\eta}} Y_{t} \\
R_{t} K_{p, t-1}=\alpha_{p} Y_{t}
\end{gathered}
$$

Different from private factors, there are no demand functions for public labor and capital because their services are freely provided by the government to the firm, which exploits them in its production process. Their main implication is making a firm's profits positive. Specifically, using the definition of profits, $\Pi_{t}=Y_{t}-R_{p, t} K_{p, t-1}-\left(1+\tau_{t}^{S S}\right) W_{p, t} L_{p, t}>0$, and substituting the optimal demands of private factors, it can be shown that in equilibrium

$$
\begin{aligned}
\Pi_{t} & =\left[1-\alpha_{p}-\alpha_{l} \frac{\mu L_{p, t}^{\eta}}{\left[\mu L_{p, t}^{\eta}+(1-\mu) L_{g, t}^{\eta}\right]}\right] Y_{t} \\
& =\left[\alpha_{g}+\alpha_{l} \frac{(1-\mu) L_{g, t}^{\eta}}{\mu L_{p, t}^{\eta}+(1-\mu) L_{g, t}^{\eta}}\right] Y_{t} \\
& >0
\end{aligned}
$$

As expected, the amount of profits is exactly equal to the public capital and public labor shares not distributed by the firm. We assumed that this profit is paid out after tax to the household who owns the firm.

\subsection{The Model: Households}

The decisions of consumers are represented by a stand-in consumer with preferences defined over consumption, and labor is decomposed into two components:

$$
U\left(C_{t}, L_{t}\right)=U\left(C_{p, t}, C_{g, t}, L_{t}\right)
$$

where $C_{p, t}$ is private consumption, and $C_{g, t}$ is the consumption of the same private good provided by the government to the consumer. We assumed that households obtain utility from public spending on goods and services. In particular,

$$
C_{t}=C_{p, t}+\pi C_{g, t} \text { with } \pi \in(0,1] .
$$

Households' preferences are described by the following instantaneous utility function:

$$
U\left(C_{t}, N_{t} \bar{H}-L_{t}\right)=\gamma \log C_{t}+(1-\gamma) \log \left(N_{t} \bar{H}-L_{t}\right)
$$

Leisure is $N_{t} \bar{H}-L_{t}$, where $\bar{H}$ is total time endowment, and it is calculated as the number of effective hours in the week times the number of weeks in a year times the population at the age of taking labor-leisure decisions, $N_{t}$, minus the aggregated number of hours worked in a year, $L_{t}$. The parameter $\gamma(0<\gamma<1)$ is the fraction of private consumption on total private income. Households consume final goods and supply labor to the private and public sectors,

$$
L_{t}=L_{p, t}+L_{g, t}
$$

where $L_{t}$ is the aggregate level of employment, $L_{p, t}$ is private employment, and $L_{g, t}$ is public employment. Public employment is chosen by the government; thus, it is exogenous to the households as a quantity constraint. At an aggregate level, a household can only 
choose the supply of private labor, $L_{p, t}=L_{t}-L_{g, t}$. Recall that public employment demand is fully covered by the household, provided that $W_{g, t}>W_{p, t}$.

The budget constraint faced by the stand-in consumer is:

$$
\begin{aligned}
& \left(1+\tau_{t}^{c}\right) C_{p, t}+K_{p, t}-K_{p, t-1} \\
= & \left(1-\tau_{t}^{l}\right)\left[W_{p, t} L_{p, t}+W_{g, t} L_{g, t}\right]+\left(1-\tau_{t}^{k}\right)\left(R_{t}-\delta\right) K_{p, t-1} \\
& +Z_{t}+\left(1-\tau_{t}^{\pi}\right) \Pi_{t}
\end{aligned}
$$

where $K_{p, t}$ is the private capital stock; $W_{p, t}$ is the private compensation per employee; $W_{g, t}$ is the public compensation per employee; $R_{t}$ is the rental rate of capital; $\delta_{K_{p}}$ is the capital depreciation rate, which is modeled as tax deductible; $Z_{t}$ are lump sum transfers and entitlements; and $\Pi_{t}$ denotes profits from firms, as defined previously. The budget constraint states that consumption and investment in physical capital cannot exceed the sum of labor and capital rental incomes and profits net of taxes. Private capital holdings evolve according to a standard law of motion, $K_{p, t}=\left(1-\delta_{K p}\right) K_{p, t-1}+I_{p, t}$ where $I_{p, t}$ is a household's gross investment.

The consumer maximizes the discounted lifetime value of utility (15) subject to the budget constraint (17), where $\left(K_{p 0}, K_{g 0}\right)$ and the paths of public employment and taxes are given, and $\beta \in(0,1)$ is the household's discount factor. This formulation implies that the wage-setting process in the private sector is standard, i.e., wages are determined in terms of their marginal products, whereas public wages are determined by the negotiation between the government and unions.

\subsection{The Model: International Investors}

The rest of the world in this economy is modeled as a single international banker whose objective is to maximize the discounted dividend $x_{t}$ obtained from the asset holdings of government bonds. The discount factor is $\beta$, identical to the consumer's discounting parameter. Purchases of government bonds are denoted by $b_{t}$. Supply and demand are equal at all times, so $B_{t}=b_{t}$.

$$
\begin{array}{r}
\max _{x_{t}} \sum_{t=0}^{\infty} \beta^{t} x_{t} \\
\text { s.t. } b_{t+1}-b_{t}+x_{t}=w^{I}+R_{t}^{b} b_{t}
\end{array}
$$

where $w^{I}$ is a constant endowment.

From the international investor's problem, we obtain

$$
\beta\left(1+R_{t}^{b}\right)=1
$$

The optimality condition (18) together with the household's optimality condition with respect to capital $K_{p}$ show that, in the long term, the net real return to capital has to equate to the real return of the government bond, including any risk premium, that is,

$$
\left(1-\tau^{k}\right)\left(R-\delta_{K_{p}}\right)=R^{B}
$$

\subsection{The Model: Equilibrium}

We solved for the perfect foresight version of the previous model. The long-term equilibrium is characterized by the following definition:

An equilibrium with rolling over for this economy is a vector of prices $\left(W_{g}^{*}, W_{p}^{*}, R_{p}^{*}, R_{g}^{*}, R^{B}\right)$ a vector of input quantities $\left(L_{g}^{*}, L_{p}^{*}, K_{g}^{*}, K_{p}^{*}\right)$, and a vector of private consumption and investment $\left(C_{p}^{*}, I_{p}^{*}\right)$, such that for a given fiscal policy summarized by a collection of taxes $\left(\tau_{c}, \tau_{l}, \tau_{k}, \tau_{s s}, \tau_{\pi}\right)$ and expenditure proportions $\left(\theta_{1}, \theta_{2}, \theta_{3}, \theta_{4}\right)$ induces a vector of public consumption, investment, transfers, and debt services $\left(C_{g}^{*}, I_{g}^{*}, Z^{*}, R^{B} B^{*}\right)$, such that the 
optimization problems of the household, the firm, and the government are satisfied so that the resources constraints are satisfied and all markets are clear.

This steady state induces a level of welfare for the consumer given by

$$
U^{*}=\frac{1}{1-\beta} U\left(C_{p}^{*}, C_{g}^{*}, L^{*}\right)
$$

For implementation, in this section, we provide a quantitative example by calibrating the model to match the Greek economy and then by comparing the results with those of a model calibrated to match the German economy. The frequency of the data is annual for the period 2002-2006, thus ending before the crisis, which was selected as the steady state for the model economy. GDP, government expenditure, public debt, private consumption, private investment, public investment, and public consumption were taken from the OECD Statistics database and from Eurostat. Data on capital stock were taken from the EUKLEMS database. Public and private compensation of employees and public and private employment were taken from OECD Economic Outlook database's December 2007 issue, for the period of 1960-2006. The public wage bill was calculated as the total final public compensation of employees. We selected the Greek economy because it is an emblematic example in the last years' public debt crises, and we compared it to Germany, which is usually used as an example of fiscal discipline. Below, we first explain how to calibrate fiscal parameters, and then move to the calibration of the parameters controlling for the rest of the economy. Finally, we explain how to set debt maturity.

\subsection{Calibration of Government Parameters}

The government in our model is defined as a vector of fiscal policy instruments' parameters $\left(\tau^{k}, \tau^{l}, \tau^{c}, \tau^{\pi}, \tau^{s s}, \theta_{1}, \theta_{2}, \theta_{3}, \theta_{4}\right)$; a stock of debt, $B$; and a fraction of debt that needs to be refinanced every period, $N$. The first set of parameters are taxes: we selected taxes on capital, labor, and consumption directly from the OECD; taxes on profits and social security contributions were taken directly from OECD statistics. The second set of parameters are expenditure shares. We took them directly from the National Accounts. For the Greek economy, public investment represents $10.37 \%$ of the expenditure, implying $\theta_{2}=0.1037$, while in the German economy, public investment accounts for only $4.32 \%$, implying $\theta_{2}=0.0432$. The expenditure share of public consumption is roughly similar for both countries $\left(\theta_{1}=0.4467\right.$ for Greece and 0.4024 for Germany). The public wage bill, $\theta_{3}$, is obtained as the public wage bill over total government expenditure $\theta_{3}=\left(1+\tau^{s}\right) W_{g} L_{g} / G$, with values of 0.2441 for Greece and 0.1712 for Germany. Putting together the different fractions of government expenditures, we obtained, as a residual, the value of $\theta_{4}=1-\theta_{1}-\theta_{2}-\theta_{3}$ as total transfers to consumers, which are 0.2055 in Greece and 0.3832 in Germany. Finally, public debt in Greece is equal to $B / Y=1.10$; in Germany, it is 0.656. All the government parameters are summarized in Table 1.

Lastly, we used the average maturity as in [33] of Greek and German debt at the time of the Great Recession (4 and 6 years, respectively) to determine the number of periods in which debt payback is followed up. Since, each period, the government has to refinance a constant fraction $1 / N$ of its total debt, the average maturity is equal to

$$
\text { maturity }=\frac{1}{N} \times 1+\frac{1}{N} \times 2+\ldots+\frac{1}{N} \times N=\frac{1}{N} \sum_{i}^{N} i=\frac{N+1}{2} \text {. }
$$

The resulting figures are $N=7$ for Greece and $N=11$ for Germany. 
Table 1. Government parameters.

\begin{tabular}{clll}
\hline Parameter & \multicolumn{1}{c}{ Definition } & \multicolumn{2}{c}{ Value } \\
\hline & & Greece & Germany \\
\hline$\theta_{1}$ & Public consumption/tot. gov't expenditure & 0.4467 & 0.4024 \\
$\theta_{2}$ & Public investment/total gov't expenditure & 0.1037 & 0.0432 \\
$\theta_{3}$ & Public wage bill/tot. gov't expenditure & 0.2441 & 0.1712 \\
$\theta_{4}$ & Public transfers/tot. gov't expenditure & 0.2055 & 0.3832 \\
$\tau^{l}$ & Labor income tax rate & 0.4100 & 0.3810 \\
$\tau^{k}$ & Capital income tax rate & 0.1640 & 0.1810 \\
$\tau^{s s}$ & Social security contribution & 0.3560 & 0.3390 \\
$\tau^{\pi}$ & Profit tax rate & 0.2500 & 0.3870 \\
$\tau^{c}$ & Consumption tax rate & 0.1480 & 0.1240 \\
$B / Y$ & Ratio public debt/output & 1.1000 & 0.6560 \\
$N$ & Fraction of debt refinanced every period & 7 & 11 \\
\hline
\end{tabular}

\subsection{Calibration of Technological and Preference Parameters}

The real return of public bonds is $R^{B}=0.041$, which corresponds to the interest rate for the Greek and German ten-year bonds in 2006. The standard no-arbitrage condition implies that $\beta=0.9606$ for both economies. Computing private and public capital depreciation rates is a difficult task, since it involves computing the types of investments and the depreciation rate for each of them. Due to its intrinsic difficulty, we used the estimates of [34] for the Spanish economy, which implies that $\delta_{K_{p}}=0.08$ and $\delta_{K_{g}}=0.04$ for both countries. The depreciation rate for public capital is lower than for private capital given their different compositions, since public capital typically contains more infrastructure, which depreciates more slowly. These calculations imply that, in the steady state, the public capital stock represents around $28 \%$ of total capital stock and that total capital stock is 3.26 times the total output for Greece, whereas for Germany, these figures are $21 \%$ and 2.5 , respectively.

We used OECD data series on public sector labor and wages. Public and private compensation of employees and public and private employment were taken from the OECD Economic Outlook database's December 2007 issue, for the period of 1960-2006. The public wage bill was calculated as the total final public compensation of employees. In 2006, public employment over private employment was $24.0 \%$ for Greece and $13.04 \%$ for Germany. The other target is the wage premium, $W_{g} / W_{p}$, which was 1.4935 for Greece and 1.1999 for Germany. Simultaneously, we observed from the same database the ratios of public labor to private labor $L_{g} / L_{p}$, which was 0.24 for Greece and 0.13 for Germany. These figures imply that both public employment and public wages were higher in Greece than in Germany. These figures are consistent with the ratio of the public wage bill over the total government spending for each economy. Since workers are paid their marginal product, we obtain that the ratio of public wages to private wages is

$$
\frac{W_{g, t}}{W_{p, t}}=\frac{1-\mu}{\mu} \frac{L_{g, t}^{\eta-1}}{L_{p, t}^{\eta-1}} .
$$

The estimation we followed is closely related to [28], which implies $\eta=0.4326$ and $\mu=0.6008$ for Greece and $\eta=0.5762$ and $\mu=0.6640$ for Germany.

We now consider compute factor shares in the production function. We used a standard no-arbitrage condition for capital and bonds to find that $R_{B}=\left(R_{p}-\delta_{p}\right) \times\left(1-\tau^{k}\right)$, where $R_{p}$ is the return on private capital investment. As $R_{p}=\alpha_{p} K_{p} / Y$, we found that $\alpha_{p}$ was 0.3005 in Greece and 0.2556 in Germany. We used the total compensation of employees over GDP to compute $\alpha_{l}$, given that in the model $\alpha_{l}=\left(W_{p} L_{p}+W_{g} L_{g}\right)\left(1+\tau^{S S}\right) / Y$. We can write this expression as a function of three previous targets as $\alpha_{l}=\left(\left(W_{p} / W_{g}\right)\left(L_{p} / L_{g}\right)+1\right) \theta_{3} G / Y$. 
We found that this number was equal to 0.3327 in Greece and 0.6026 in Germany for a $G / Y$ of 0.36 for Greece and 0.48 for Germany. Finally, $\alpha_{g}$ was found as the residual so the sum of shares equals 1 in each country.

Finally, we calibrated $A$ to normalize output in the economy to 100 . To this end, we used expression

$$
A=\frac{Y}{K_{p}^{\alpha_{p}} K_{g}^{\alpha_{g}}\left[\mu L_{p}^{\eta}+(1-\mu) L_{g}^{\eta}\right]^{\frac{\alpha_{l}}{\eta}}},
$$

evaluated at $Y=100$ for the two countries. Similarly, we set $\gamma$ in order for the labor supply equation to generate the observed labor force participation, $L / H=0.5750$ in Greece and $L / H=0.7017$ in Germany, using equation

$$
\gamma=\frac{C_{p}+C_{g}}{C_{p}+C_{g}+\left(H-L_{p}-L_{g}\right) W_{p} \frac{1-\tau_{l}}{1+\tau_{k}}},
$$

which implies $\gamma=0.8956$ in Greece and $\gamma=0.8792$ in Germany. All the parameters for the economy are reported in Table 2.

Greek figures for taxes, fiscal revenues, total government spending, and its distribution are not so different from the figures for the rest of the countries in the Euro area. The tax menu is similar to countries such as Germany. The fiscal-revenue (including social security contributions)-to-GDP ratio for Greece is in line with the rest of the Euro-area countries and even higher than countries such as Ireland. Furthermore, the government-spendingto-GDP ratio was about $45 \%$ for Greece compared to $47 \%$ for Germany or $53 \%$ for France, and the public-to-private-labor ratio was around 24\% for Greece compared to about 32\% for France.

Table 2. Calibration of the economy.

\begin{tabular}{llll}
\hline Parameter & Definition & \multicolumn{2}{c}{ Value } \\
\hline$\beta$ & & Greece & Germany \\
\hline$\delta_{K p}$ & Discount factor & 0.9606 & 0.9606 \\
$\delta_{K g}$ & Private capital depreciation rate & 0.0800 & 0.0800 \\
$\eta$ & Public capital depreciation rate & 0.0400 & 0.0400 \\
$\mu$ & Public-private labor elasticity of substitution & 0.4326 & 0.5762 \\
$\alpha_{p}$ & Private employment weight & 0.6008 & 0.6640 \\
$\alpha_{l}$ & Private capital income share & 0.3005 & 0.2556 \\
$\alpha_{g}$ & Labor share & 0.3327 & 0.6026 \\
$A$ & Public capital technical parameter & 0.3668 & 0.1418 \\
$\gamma$ & TFP & 1.2015 & 1.6422 \\
\hline
\end{tabular}

\subsection{Public Debt Frontier}

Once the model is set and the equilibrium solution is characterized, we built the PDF by performing the following steps:

1. We calibrated the model using the information provided in Section 3.7 to match the characteristics of the private sector and in Section 3.8 to match the characteristics of the public sector.

2. For each value of government's primary spending, we numerically simulated a perfect foresight version of the model computing GDP and the associated maximum amount of sustainable debt in a steady state with rolling over.

3. Two steady-state ratios from previous simulations were plotted as a pair of coordinates in a diagram: $G / Y$ and $B / Y$. Then, the simulations were repeated for each possible level of primary spending, and the corresponding ratios were depicted. The PDF was obtained by joining all of the resulting pairs of coordinates. 
Figure 2 depicts the frontier for each fiscal ratio $G / Y$. Note that sustainable debt limits stand here for the level at which fiscal income is sufficient to cover current government expenditures plus the service of debt. This notion of a sustainable debt limit coincides with that of constant long-run debt and, thus, constant bond yields in a model with an endogenous risk premium.

From the model, we obtained a numerical representation of the trade-off between the sustainable long-term public debt limit and government size measured as the totalgovernment-spending-to-GDP ratio. A larger government size, given a constant level of public revenues, corresponds to a lower long-term sustainable level of public debt. The debt frontier is the relationship between the public-expenditure-to-GDP ratio, $G / Y$, and the total-debt-to-GDP ratio, $B / Y$, implied by the government budget constraint. Above the curve, we have all pairs where, given the ratio $G / Y$, the amount of endogenous fiscal revenues are not enough to cover the services of total debt, $R^{B} B$. Below the curve, we have all data pairs where fiscal revenues suffice to cover the given $G / Y$ ratio and services the outstanding debt. Figure 2 shows that the ratios of public expenditures and total debt are very far from the debt limit, calculated with the real return of bonds set at $1 \%$ for the period of 2002-2006. Figure 2 also plots the actual values of the $G / Y$ and $B / Y$ ratios for the period of 2002-2006, shown in Figure 3 as a time series. These ratios remained almost constant for the period 2002-2006 at a value of total public spending/GDP of $45 \%$ and a public debt/GDP of around $100 \%$. The intuition behind this result is simple: in our model, public debt is modeled as if bond markets are infinitely liquid and, thus, any maturing bond can always be rolled over at the given rate in the steady state. In this context, the long-term sustainable amount of debt depends on both public revenues and expenditures and on the public bond interest rate. The sustainable debt limit is increasing in public revenues and decreasing in public expenditure and the bond interest rate. A negative shock to output will reduce both the public-income/output ratio and the public-expenditure/output ratio, driving the economy toward the long-run unsustainable debt area and reducing the long-run sustainable amount of debt.

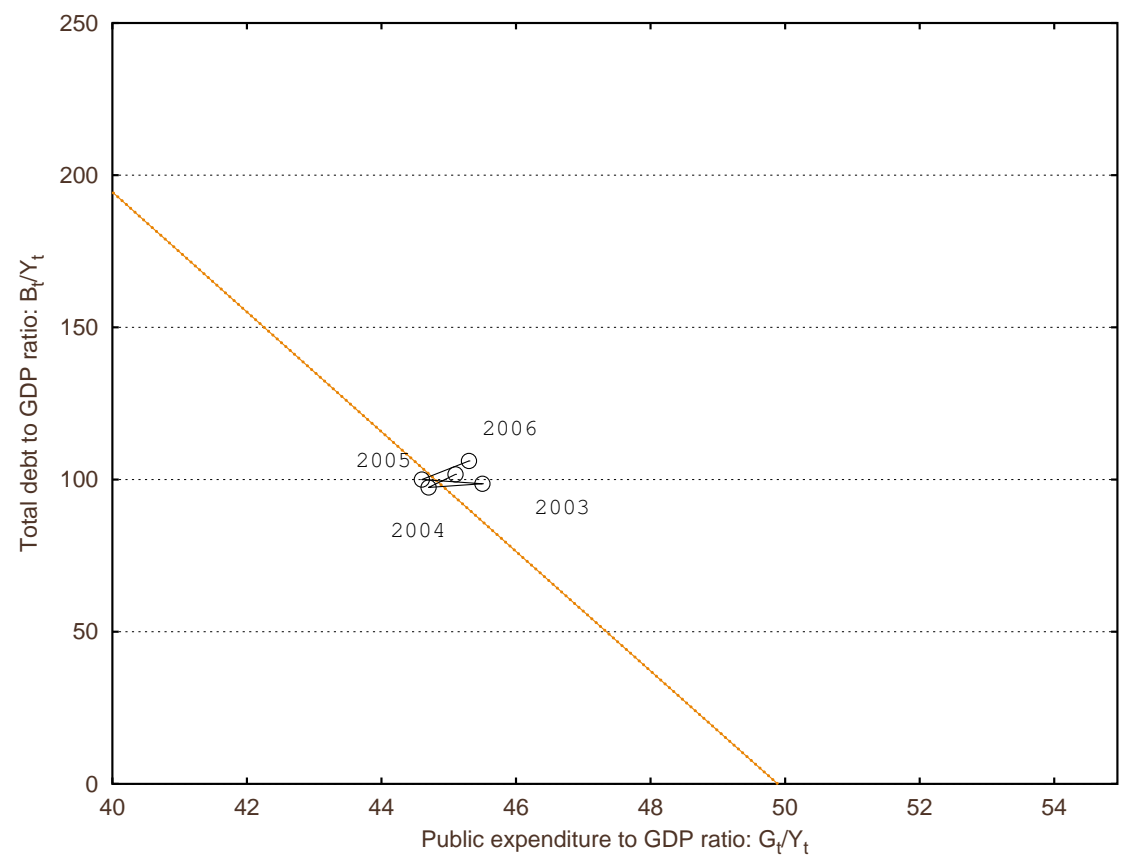

Figure 2. The debt frontier 2002-2006, Greece. 


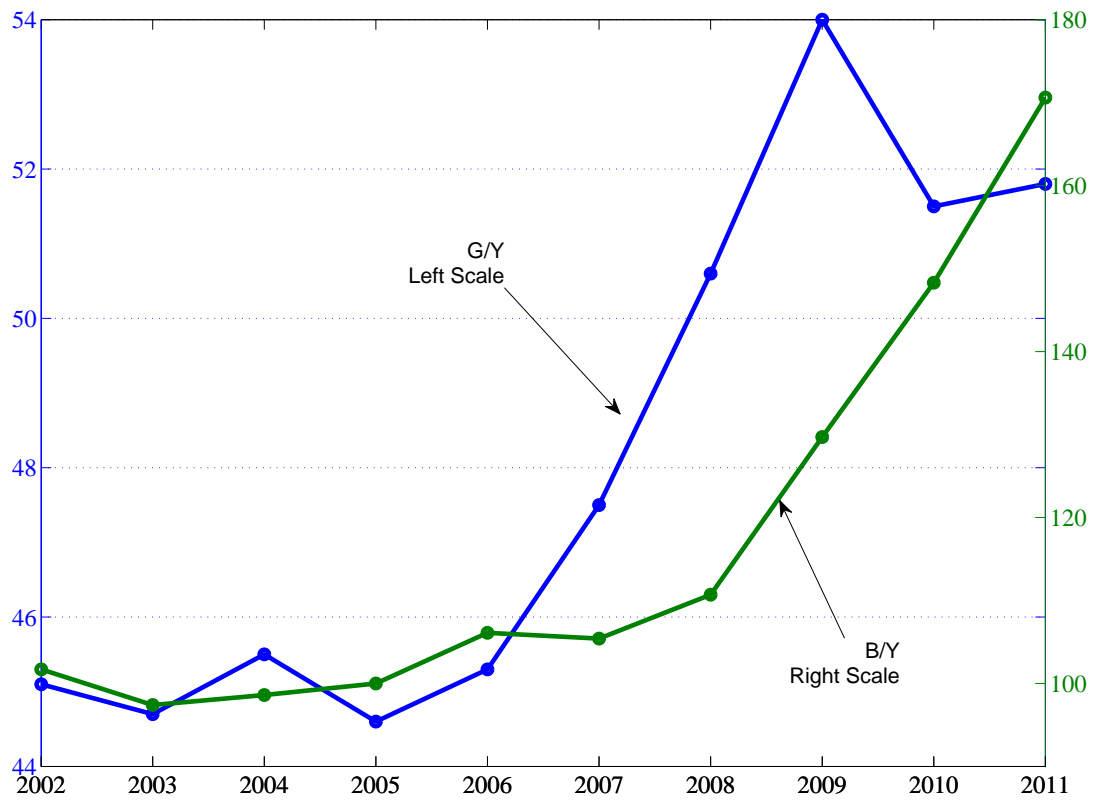

Figure 3. Expenditures and debt 2002-2011, Greece.

\subsection{A Python Toolkit for Policy Evaluation}

In this section, we present the Python software developed for this study and available among the additional online material to this publication (see Supplementary Materials). When executing the code in a Python installation, a main window opens as the one represented in Figure 4 . It contains the preloaded parameters of the country of choice. Figure 4 shows four panels with data. Each of the panels collects the parameter values of each of the four institutional sectors in the model economy: government, households, technology (represented by firm and labor unions), and the external sector represented by an international interest rate with a country-specific risk premium, together with the current debt-to-GDP ratio that is steadily rolled over period-by-period.

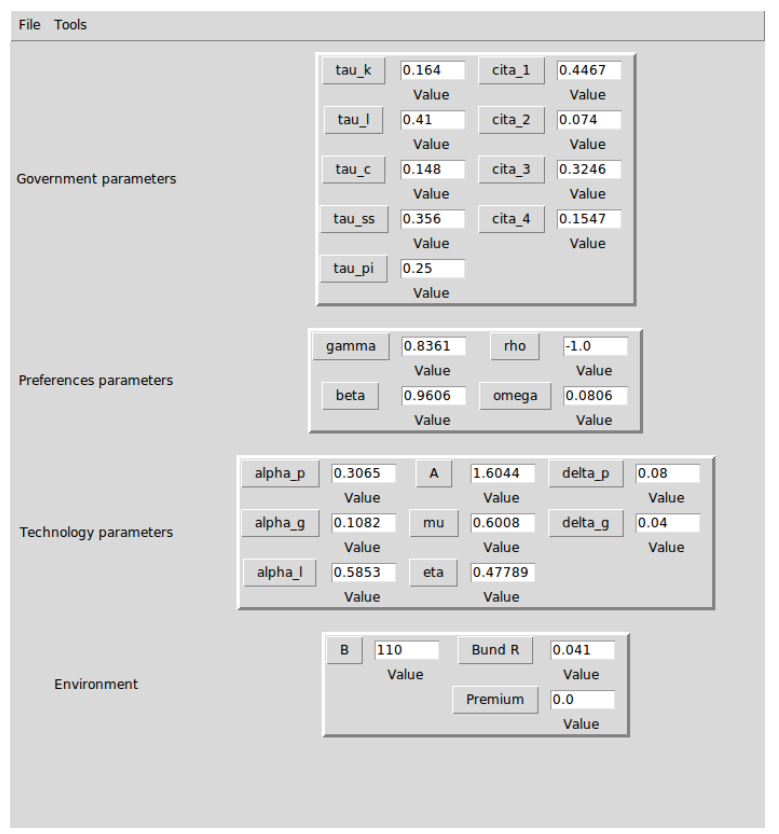

Figure 4. Main window of the application. 
From the top menu of the application, we can select the submenu "File," where a drop-down menu unfolds showing a set of options depicted in Figure 5. In this menu, we can select parameters for government, technology, household preferences, and the foreign sector. It is also possible to download the parameter set of a whole country from ttxt or .xlsx files as shown in Figure 6.

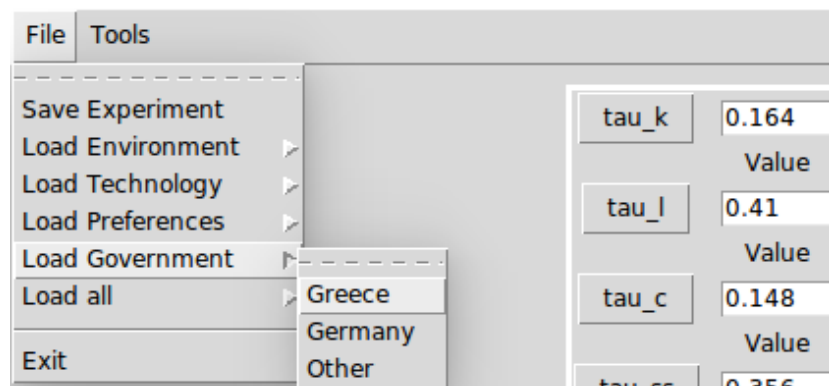

Figure 5. File menu.

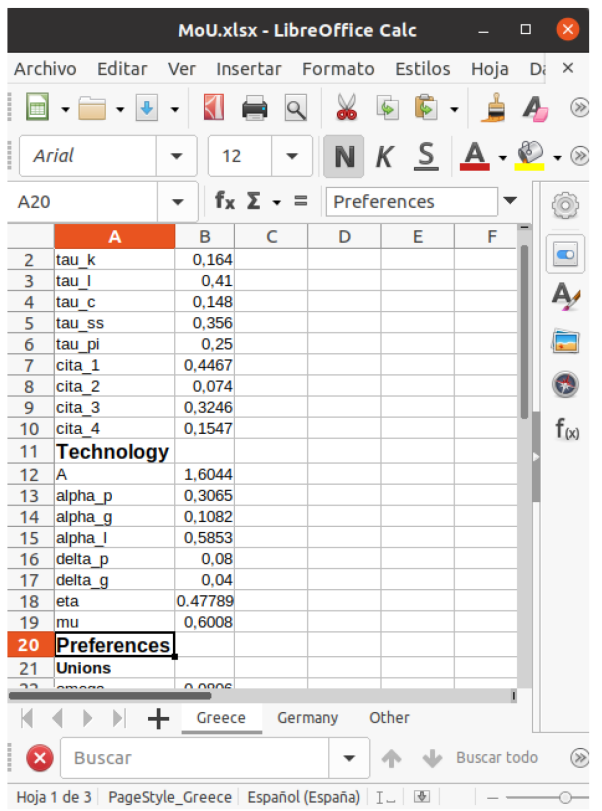

Figure 6. File Greece.xslx.

Note that this allows the creation of mixed economies with, for example, Italian technology, German government, Japanese debt, and American households. Once the economy has been selected, from the "Tools" menu, we can execute the experiment we want to run. Figure 7 displays the single drop-down menu that allows the user to run the experiment once the parameter set has been selected to the desired mixture of economies.

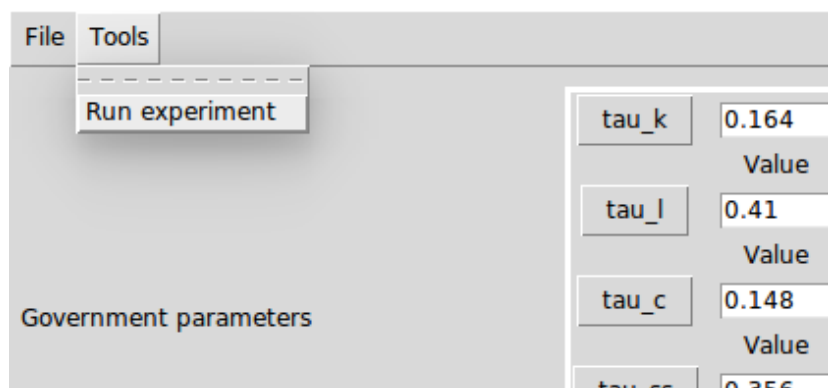

Figure 7. Tools menu. 
Once the "Run Experiment" option is chosen, a window pops up on the screen that contains the public debt frontier computed with the model presented in the study, together with the parameter selection. Figure 8 displays the calculated frontier superimposed on data consisting of triplets $[(G / Y, B / Y)$, year].

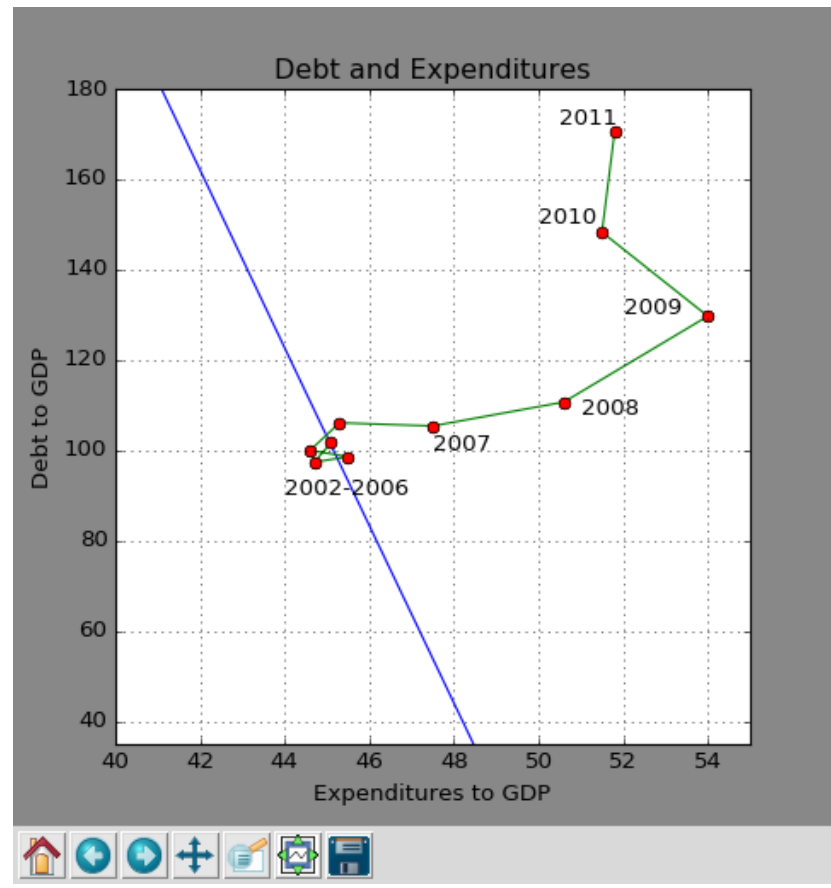

Figure 8. Pop up window with the debt frontier.

In the following, we provide some examples of this software. In particular, we analyze the reaction of debt sustainability to fiscal shocks. As in our calibration, the preloaded country is Greece (see Figure 9).

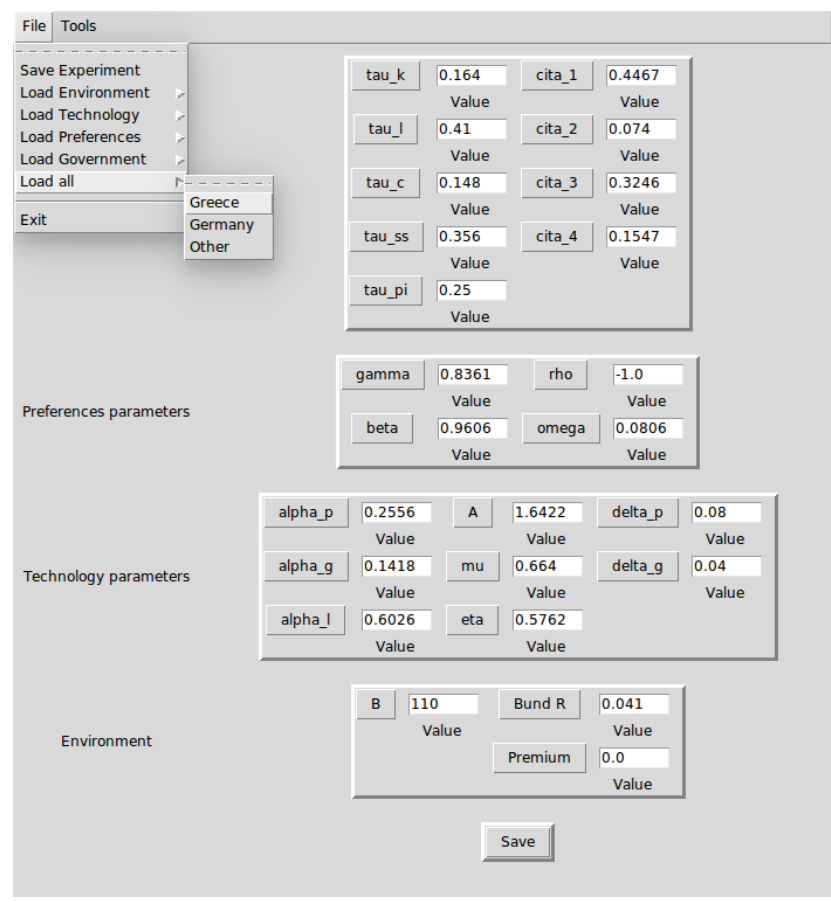

Figure 9. Loaded Greek parameters. 


\section{Results}

\subsection{Debt Sustainability after Tax Hikes}

In this experiment, we wanted to know if Greece could have improved its debt sustainability had it assumed the German tax code. To run this experiment, we first executed the application as a Python executable. From the top menu, choose File $\rightarrow$ Load all $\rightarrow$ Greece, as shown in Figure 10, to fill all parameters with the values taken from the file MoU.xlsx, shown in Figure 6. Once the data are loaded into the application, execute Tools $\rightarrow$ Run experiment, and the resulting pop-up is shown in Figure 8. It contains two elements: the frontier and a collection of points in the space $(G / Y, B / Y)$, together with a year associated to each point. Note that the line passes through the cluster of points marked 2002-2006. Those are the years used for the calibration of the PDF, in which debt is sustainable by construction, and thus the frontier has to pass trough those points. Once the crisis hit Greece (2007), the negative shock on $Y$ swings the ratio $G / Y$ to the right. This movement makes the current situation unsustainable in the long term. As we can see, the Greek government took 2 years to reduce spending $G$ as a percentage of $Y$, and, therefore, the data points move toward the right until 2009, making the level of debt more unsustainable. Eventually, the government managed to cut primary spending, but debt service and the economic recession pushed the debt-to-GDP ratio upward (2009-2011). To improve their financial situation, we asked whether the Greek government adopting the German tax code would have improved debt sustainability in Greece. To perform this experiment, we returned to the main window of the application and selected the precreated file with the German policy vector (File $\rightarrow$ Load Government $\rightarrow$ Germany), as shown in Figure 11.

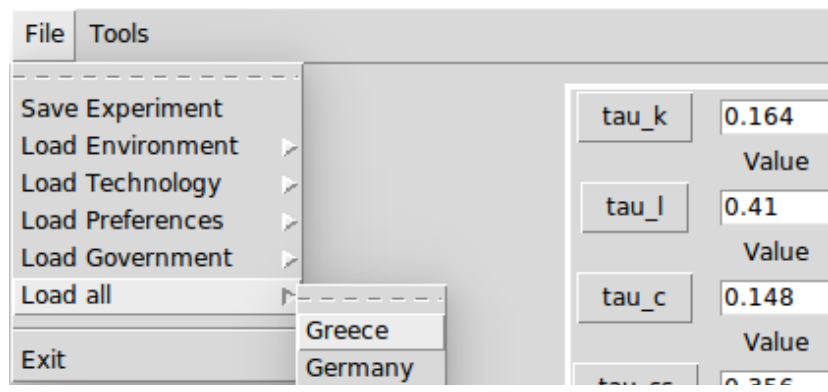

Figure 10. Loaded Greek parameters.

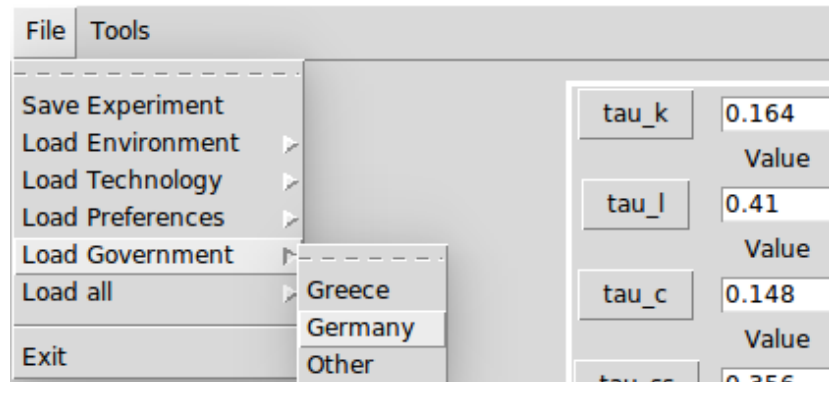

Figure 11. Loaded German fiscal parameters.

Once the German tax code was loaded, we ran the experiment again with Tools $\rightarrow$ Run experiment. The output of the experiment was a new PDF showing the sustainability thresholds for the Greek debt backed by a German fiscal system. Figure 12 shows that this PDF is at the left of the original one; thus, sustainability deteriorates in this case. 


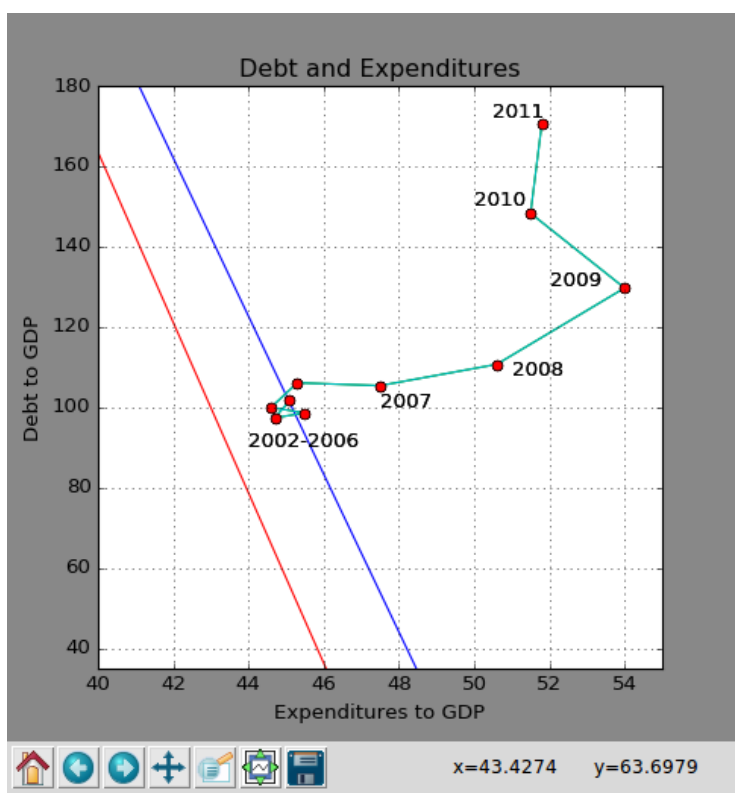

Figure 12. E1, Greece with German taxes.

\subsection{Debt Sustainability after a Fully Fledged Fiscal Consolidation}

In this experiment, we checked whether fiscal prescriptions such as the one received by Greece from the Troika (ECB, EC, and IMF) would have improved the sustainability of Greek debt. We characterized the policy mandate with a set of economic policies oriented to increasing productivity; together with a fiscal package to decrease spending that includes increases in the VAT, labor taxes, and corporate taxes, plus a restructuring of public expenditures increasing public investment at the expense of transfers.

The proposed combination increases the following vector of policy instruments $\left(\tau_{k}, \tau_{l}, \tau_{\pi}, \theta_{3}\right)$ by $10 \%$. This would depress output by $-2.37 \%$; private and public consumption by $-2.30 \%$ and $-2.37 \%$, respectively; and depress total investment by $-4.98 \%$, but it would increase the debt ceiling by $24.47 \%$, as shown in Figure 13.

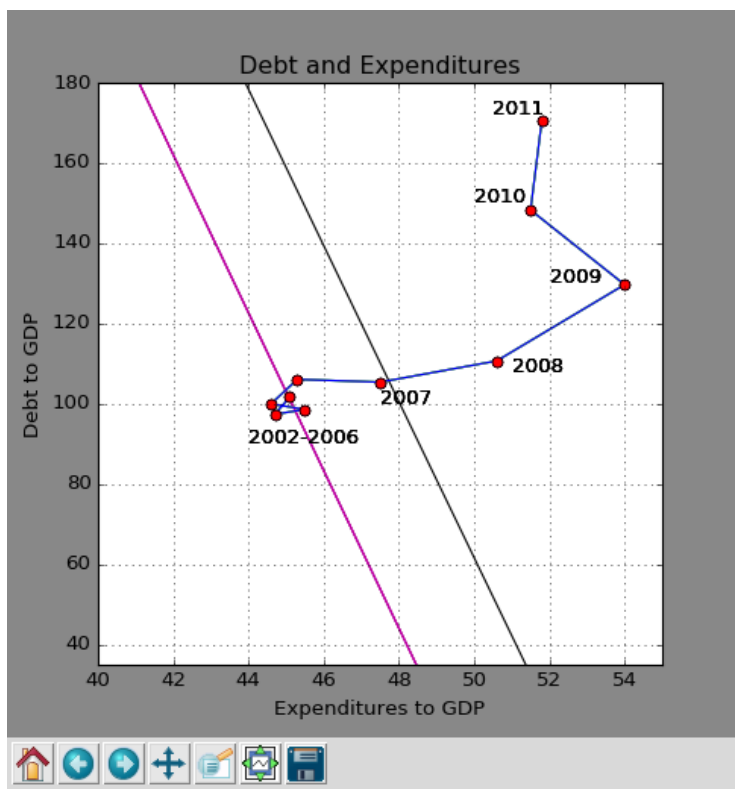

Figure 13. E2, Greek reform. 


\subsection{Debt Sustainability after Increases in the Interest Rate}

We complete our analysis with a variation in the yield. Figure 13 shows how the frontier moves inward as a consequence of an increase in the yield of the Greek bond. We represent the frontier for $4 \%, 5 \%$, and $7 \%$ yields, recalibrating the other parameters' values of the model economy to the new interest rate. Notice that the effective spreads of the Greek bond with respect to the German bond were much larger. Since the beginning of the negotiations of the details of the rescue package for Greece by April 2010, the spreads skyrocketed for a number of reasons. One of those reasons is discussed in Chamley et al. [35]. They argue that the seniority of the new bonds issued to finance the rescue program would disincentivize other private investors from buying Greek bonds. However, we agree with [36] in saying that the rescue package was an effective mechanism to provide liquidity to the Greek state at a controlled yield. Figure 13 shows that the fiscal ratios displayed by the Greek economy prior to the crisis were sustainable at a yield of $5 \%$, that is, the real return of the rescue package bond was consistent with the long-term sustainability of Greece prior to the unfolding of events that drove Greece to the current crisis. Nevertheless, the pre-crisis figures were unsustainable at the yield of $7 \%$, as shown in Figure 14.

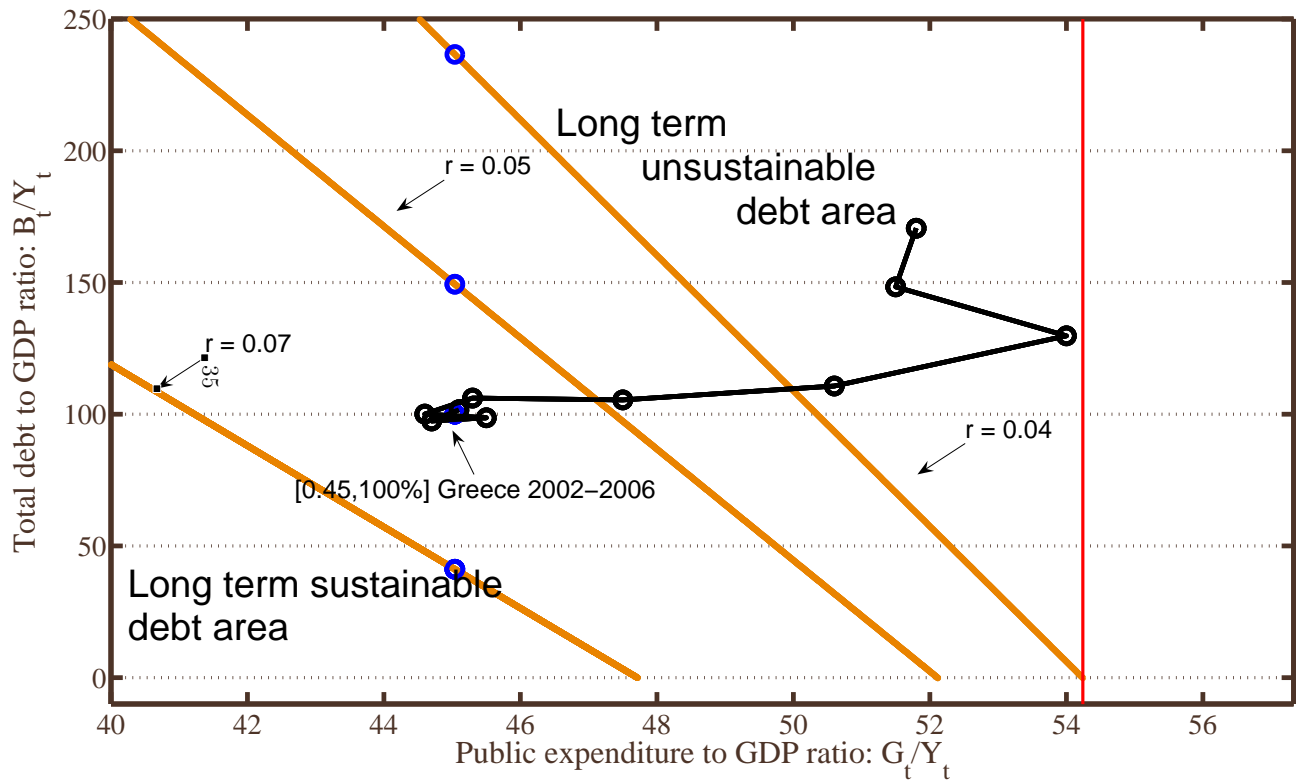

Figure 14. The frontier at different real rates.

\section{Discussion}

The experiments performed in Section 4 highlight several results. In Section 4.1, we learned that contractionary fiscal policy in an economy experiencing a public debt crisis may have the undesirable effect of driving public debt further away from a sustainable path. As shown in Figure 12, after tax hikes, the PDF shifts to the left because the maximum amount of sustainable debt is now lower. This result explains why sustainability deteriorates, which is due to the contractionary effect of fiscal policy. In a general equilibrium framework, tax bases are endogenous. Higher (distortionary) taxes eventually reduce income and tax bases, thus offsetting the positive effect of higher tax rates on tax revenues. Additionally, the contractionary effect of higher taxes on production further diminishes the level of sustainable debt by reducing GDP (the snowball effect). Note that this result is opposite to what we would have obtained in a DSA, in which tax bases are constant and fiscal income only depends on marginal taxes.

Overall, the experiment in Section 4.1 indicates that a more effective policy for the government to attain financial solidity is to foster productivity and competitiveness in the country with the goal of increasing GDP. Section 4.2 presents an experiment based on 
such a policy mandate, in which the government implements supply policy that increases productivity paired with fiscal austerity in the form of tax increases and government spending reductions. As illustrated in Figure 13, such heterogeneous policy is effective in improving sustainability in the country, raising the maximum amount of sustainable debt by 24 percentage points of the GDP.

Section 4.3 focuses on the importance of the interest rate. The experiment had a twofold purpose: First, because the interest rate is exogenous in our model, we used the experiment to run a sensitivity analysis of debt sustainability when the interest rate varies. Second, from a policy perspective, it shows the importance of public debt purchases from supernational authorities such as the ECB, which can effectively cap the interest rate on debt service below the market rate. As shown in Figure 13, the large shifts in the PDF generated by small variations in the interest rate $\left(\Delta i_{t} \pm 1 \%\right)$, suggest that reducing the interest rate on debt service is a key point for a country in financial distress to maintain sustainable public debt while implementing more structural supply and fiscal policies.

Some remarks and limitations of the previous analysis are worth highlighting. First, for public debt to return to a sustainable PDF, in our analysis, government spending has to attain a reduction that is the sum of three components: (i) the reduction in spending needed to fund the repayment of the excess debt, (ii) the additional reduction needed to cover for the loss of tax revenues generated by lower tax bases, and (iii) the nominal reduction in the level of debt needed to re-establish the sustainability of the debt-to-GDP ratio in the presence of a lower GDP. Items (ii) and (iii) imply additional public saving because, in our backing theory, fiscal consolidations are contractionary. This feature of the model is due to the assumption of public production goods and to the calibration adopted, for which the economy is in the echelon of the Laffer curve with a positive derivative.

However, this depends on the chosen model, and it may not be the case as noted by Alesina et al. [37]. In a model featuring expansionary fiscal consolidations, the generalequilibrium effects (ii) and (iii) would operate on sustainability in an opposite direction to the direct effect (i), thus suggesting smaller reductions in public spending $G_{t}$ to attain sustainability. Note that the PDF associated with that model would consistently account for it, eventually providing the overall fiscal adjustment needed to attain debt sustainability consistent with the general equilibrium effects present in the model. In other words, the frontier is robust to the modeling choices in terms of the sign and the size of fiscal multipliers.

Second, the model used to implement the frontier is a real neoclassical model augmented with endogenous tax revenues, disaggregated public spending, different production technologies for public and private goods, nonatomistic wage setters in public labor (unions), and a fully specified maturity curve for public bonds. The neoclassical framework has has some limitations itself. Fiscal policy cannot affect GDP in the long term. We avoided this result by assuming that fiscal policy has a non-negligible effect on the aggregate demand. Additionally, the assumption of deep-pocket international investors is used to overcome Ricardian equivalence arguments. However, this only implemented a strong sustainability condition by dictating that public debt is sustainable only if total deficit is zero in the long term. Thus, our model is silent on debt dynamics and its sustainability in the short run. We also assume that the interest rate is exogenous, whereas the literature on empirical DSA highlighted several refinements to this theory: debt-dependent risk premia affecting the interest rate, debt adjustment equations to more realistically describe the short-term debt dynamics and public bonds emissions, and long-term sustainability in the presence of GDP growth over the balanced growth path (our model has no growth). Additionally, the model could be improved by describing the technology of the economy by a more general C.E.S. production function in both labor and capital. By assuming that all technologies are Cobb-Douglas, we are also assuming that all technical elasticities of substitution are equal to one in all countries. This is an obvious limitation of the model, since labor market regulations limit the extent to which a country can substitute capital and labor. The impact of the elasticity of substitution on debt sustainability can be important. As the international cost of debt evolves over time, the arbitrage condition operating 
inside the economy changes the return to capital. However, if legal regulation prevents the introduction of labor-saving technologies, unemployment has to increase as nonviable firms have to shut down. The increase in unemployment obviously affects GDP and, in turn, public debt sustainability. Note that all these elements are model-specific and not limitations of the frontier.

Finally, the Python toolkit also has some limitations. For example, the programming languages of Python 2 and Python 3 are incompatible. To develop this toolkit, we used the legacy version (Python 2), and in the future we may need to translate our code to Python 3. Python is slower than Java or C+, even though it is faster than MATLAB or GNU-Octave (see [38]). Python is not self-contained, but it requires module support that sometimes lacks adequate inputs. The libraries used to develop this toolkit are standard and thus constantly supported, but, as mentioned above, we will need to keep up with possible newer versions of Python to enjoy support in future. Another limitation is that the present version of the software works as a standalone program for computers, and this limits its usage to an audience that manages Python on PCs. However, Python code can be easily embedded in the programming codes of html webpages, flash applications, or smartphone/tablet apps (both html5 and Java), which are all compatible with Python. Thus, in our future research, our next step is the implementation of the toolkit in a webpage in which a remote server runs the Python machine at user request, and final users only have to deal with the GUI and choosing their calibration data.

\section{Conclusions}

Policymakers can use two alternative instruments to assess public debt sustainability. The first option consists of using reduced-form models in which debt dynamics are typically a function of primary or total fiscal balance, GDP (both level and growth), inflation, and the interest rate. This approach is simple, comprehensible, and, possibly for these reasons, widely used in policy practice. Their usefulness, however, comes at the cost of robustness as the values assumed for GDP growth, inflation, the interest rate, and the variables that appear in sustainability equations are taken outside the model, and they can be inconsistent with the actual debt dynamics, apart from being possibly arbitrary. The second approach consists of using modern macroeconomic (DSGE) models, in which debt sustainability is inferred from the numerical solution of the model together with other macro aggregates (and consistent with them). This second approach is more sophisticated and grounded on solid theoretical relationships among key macroeconomic variables. As with the other approach, it also has a number of drawbacks. Sustainability prescriptions depend on government budgeting and fiscal rules defined within the model, which can be fairly simpler than those estimated using reduced-form equations. DSGE models have no closed-form solution; hence, no explicit analytical relationship between debt and other macroeconomic variables can be derived, which also hinders their utility as a policy tool. This study proposed a method to overcome the last problem using a framework in which key information regarding debt sustainability from a DSGE model can be summarized in a synthetic visual indicator. Original software was developed to perform a number of experiments presented in the article, and this software contributes to spreading the use of structural models to make policy prescriptions about debt sustainability because it allows the interest audience to test debt sustainability without requiring knowledge of the technicalities of DSGE models. The PDF consists of the numerically estimated relationship between the government-spending-to-GDP ratio and the debt-to-GDP ratio resulting from the calibration of a dynamic general equilibrium model.

In this article, we presented an application of the frontier with a real case economy. We developed a DSGE model in which both fiscal income and government expenditure are characterized in detail, and we used it to assess the effect of fiscal policy on the evolution of public debt sustainability. Our theory suggests that, contrary to common knowledge, the usual fiscal consolidation measures that are required by international institutions to countries in financial distress would have had not only harsh effects on the Greek 
economy but also the undesired result of making public debt less sustainable in the long run. To improve debt sustainability, we showed that fiscal tightening should have been accompanied by a mix of policy fostering productivity. In addition, the model argues that public debt yields are crucial to attain sustainability once excess fiscal deficit is in place. This result would explain why a country like Greece struggled to find an agreement with international institutions to guarantee the bailout at the time of the public debt crisis (2010-2012). Having credible, deep-pocket institutions backing and purchasing public debt turns out to be the most efficient way to get closer to the sustainability frontier, once a country has large macroeconomic imbalances. In this case, the price effect of the interest rate is larger than the real effect of fiscal adjustment, thus indicating that the first action in case of financial distress is for the government to cap the risk premia.

Previous results are of course conditioned on the limitations of our model. Additionally, the PDF is a by-product of a particular theoretical model, and, hence, the computation of the level of debt sustainability is model-dependent. Specification and key assumptions about the model economy would presumably lead to different estimations of the level of debt sustainability, principally regarding how the roles of the government are modeled. Furthermore, the parameters of the model must be calibrated. Hence, any quantitative result derived from the model depends on the specific calibration values. It is worth noting that all of these problems are not specific to the PDF, and they can be solved by the intensive use of sensibility analysis regarding both assumptions on the functional forms and the calibration of model parameters. In general, the study shows that the development of our toolkit can be a valuable and powerful instrument for policymakers, not only for debt sustainability issues but also for the design and implementation of fiscal policy and their impact on debt dynamics.

Supplementary Materials: Supplementary materials can be found at https://www.mdpi.com/ article/10.3390/su132313260/s1.

Author Contributions: Conceptualization, G.F.d.-C. and B.M.; methodology, G.F.d.-C. and B.M.; software, G.F.d.-C.; validation, G.F.d.-C. and B.M.; formal analysis, G.F.d.-C. and B.M.; investigation, G.F.d.-C., B.M. and J.L.T.; resources, G.F.d.-C. and B.M.; data curation, G.F.d.-C. and B.M.; writingoriginal draft preparation, G.F.d.-C. and B.M.; writing-review and editing, G.F.d.-C. and B.M.; visualization, G.F.d.-C. and B.M.; supervision, G.F.d.-C. and B.M.; project administration, J.L.T.; funding acquisition, G.F.d.-C. and J.L.T. All authors have read and agreed to the published version of the manuscript.

Funding: This research was funded by Ministerio De Ciencias e Innovación (Gobierno de España) grant numbers PID2019-107161GB-C31 and ECO2013-48884-C3-3 and Consejería de Transformación Económica, Industria, Conocimiento y Universidades (Junta de Andalucía) grant number PAIDI2017SEJ122. Open access was funded under the CRUE/CSIC-MDPI agreement. The funding charge was provided by Universidad de Málaga/CBUA.

Institutional Review Board Statement: Not applicable.

Informed Consent Statement: Not applicable.

Data Availability Statement: Data on government expenditures, GDP, public debt, private consumption, private investment, public investment, and public consumption were taken from the OECD database on national accounts available online at: stats.oecd.org (accessed on 30 September 2016 Data on private capital stock were taken from the EU-KLEMS database at www.euklems.net (access on 30 September 2016). Public and private compensation of employees and public and private employment data were taken from OECD Economic Outlook (December 2007 issue). The public wage bill was calculated as the total final public compensation of employees. The real return of Greek bonds was matched to the 10-year bond yields, whose data were taken from the Bloomberg database. The average maturity of debt was taken from www.pdma.gr/index.php/en/public-debtstrategy / public-debt/historical-characteristics / (accessed on 30 September 2016) using data on the weighted-average cost maturity of annual funding. The frequency of the data was annual, and the sample date ranged from 2002 to 2011. The steady state of the model was calibrated using the subsample from 2002-2006. 
Acknowledgments: We acknowledge the helpful comments and suggestions on this project from Luca Gambetti, Luis Puch, Luis Gautier, Karlo Marques Junior, Francesco Turino, Celso Costa Junior, and Luis Franjo and the participants at the THUIT-2016 seminar (U. Complutense de Madrid), the MOVE workshop (IAE, Barcelona), and the 17th SAET Conference on Current Trends in Economics.

Conflicts of Interest: The authors declare no conflict of interest.

\section{References}

1. Alcidi, C.; Gros, D. Debt Sustainability Assessments: The State of the Art; Technical Report 122; IN-DEPTH ANALYSIS; Economic Governance Support Unit (EGOV): Brussels, Belgium, 2018.

2. Blanchard, O.; Dell'Ariccia, G.; Mauro, P. Rethinking Macroeconomic Policy. J. Money Credit Bank. 2010, 42, 199-215. [CrossRef]

3. Blanchard, O.; Dell'Ariccia, G.; Mauro, P. Rethinking Macro Policy II: Getting Granular; Technical Report 3, Staff Discussion Notes; IMF: Washington, DC, USA, 2013.

4. Feldstein, M. Rethinking the Role of Fiscal Policy. Am. Econ. Rev. 2009, 99, 556-559. [CrossRef]

5. Alesina, A.; Favero, C.; Giavazzi, F. The Output Effect of Fiscal Consolidations. J. Int. Econ. 2015, 93, S19-S42. [CrossRef]

6. Leeper, E.M.; Li, B. Surplus-debt regressions. Econ. Lett. 2017, 151, 10-15. [CrossRef]

7. Ghosh, A.R.; Kim, J.I.; Mendoza, E.G.; Ostry, J.D.; Qureshi, M.S. Fiscal Fatigue, Fiscal Space And Debt Sustainability In Advanced Economies. Econ. J. 2013, 123, 4-30. [CrossRef]

8. Mendoza, E.; D'Erasmo, P.; Zhang, J. What is Sustainable Public Debt? In Handbook of Macroeconomics; Elsevier: Amsterdam, The Netherlands, 2016; Volume 2B, Chapter 32, pp. 2493-2597.

9. $\mathrm{Bi}, \mathrm{H}$. Sovereign default risk premia, fiscal limits, and fiscal policy. Eur. Econ. Rev. 2012, 56, 389-441. [CrossRef]

10. Ko, J. Does an active fiscal policy work under a high level of government debt? Appl. Econ. Lett. 2015, 22, 1083-1088. [CrossRef]

11. Bi, H.; Shen, W.; Yang, S.C. Debt-dependent effects of fiscal expansions. Eur. Econ. Rev. 2016, 88, 142-157. [CrossRef]

12. Alesina, A.; Barbiero, O.; Favero, C.; Giavazzi, F.; Paradisi, M. Austerity in 2009-2013. Econ. Policy 2015, 30, 383-437. [CrossRef]

13. Alesina, A.; Barbiero, O.; Favero, C.; Giavazzi, F.; Paradisi, M. The Effects of Fiscal Consolidations: Theory and Evidence; Technical Report 23385, NBER Working Paper; NBER: Cambridge, MA, USA, 2017.

14. Wang, S.L. Fiscal stimulus in a high-debt economy? A DSGE analysis. Econ. Model. 2021, 98, 118-135. [CrossRef]

15. Zhang, X.; Zhang, Y.; Zhu, Y. COVID-19 Pandemic, Sustainability of Macroeconomy, and Choice of Monetary Policy Targets: A NK-DSGE Analysis Based on China. Sustainability 2021, 13, 3362. [CrossRef]

16. Ganbayar, G. Analysis of External Debt Sustainability in Mongolia: An Estimated DSGE Approach. Sustainability 2021, 13, 8545. [CrossRef]

17. Stähler, N.; Carlos Thomas, C. FiMod-A DSGE model for fiscal policy simulations. Econ. Model. 2012, 29, 239-261. [CrossRef]

18. Briceño, H.R.; Perote, J. Determinants of the Public Debt in the Eurozone and Its Sustainability Amid the Covid-19 Pandemic. Sustainability 2020, 12, 6456. [CrossRef]

19. Domeij, D.; Ellingsen, T. Rational bubbles and public debt policy: A quantitative analysis. J. Monet. Econ. 2018, 96, 109-123. [CrossRef]

20. Forni, L.; Monteforte, L.; Sessa, L. The macroeconomics of fiscal consolidations in euro area countries. J. Econ. Dyn. Control 2010, 34, 1791-1812. [CrossRef]

21. Ramos-Herrera, M.D.C.; Prats, M.A. Fiscal Sustainability in the European Countries: A Panel ARDL Approach and a Dynamic Panel Threshold Model. Sustainability 2020, 12, 8505. [CrossRef]

22. Fatás, A.; Summers, L.H. The permanent effects of fiscal consolidations. J. Int. Econ. 2018, 112, 238-250. [CrossRef]

23. Ramos-Herrera, M.D.C.; Sosvilla-Rivero, S. Fiscal Sustainability in Aging Societies: Evidence from Euro Area Countries. Sustainability 2020, 12, 10276. [CrossRef]

24. Reinhart, C.; Reinhart, V.; Rogoff, K. Dealing with Debt. J. Int. Econ. 2015, 96, S43-S55. [CrossRef]

25. Antosiewicz, M.; Lewandowski, P.; Witajewski-Baltvilks, J. Input vs. Output Taxation-A DSGE Approach to Modelling Resource Decoupling. Sustainability 2016, 8, 352. [CrossRef]

26. Stoian, A.; Obreja Brașoveanu, L.; Brașoveanu, I.V.; Dumitrescu, B. A Framework to Assess Fiscal Vulnerability: Empirical Evidence for European Union Countries. Sustainability 2018, 10, 2482. [CrossRef]

27. DeCordoba, F.G.; Pujolas, P.; Torres, J.L. Fiscal Discipline and Defaults. Rev. Econ. Dyn. 2017, 24, 1-13. [CrossRef]

28. DeCordoba, F.G.; Pérez, J.; Torres, J.L. Public and Private Sector Wages Interactions in a General Equilibrium Model. Public Choice 2012, 150, 309-326.

29. Oswald, A.J.; Grout, P.A.; Ulph, D.T. Uncertainty, Unions and the Theory of Public Sector Labor Markets; Technical Report 176; Princeton University, Industrial Relations Section: Princeton, NJ, USA, 1984.

30. Ardagna, S. Fiscal policy in unionized labor markets. J. Econ. Dyn. Control 2007, 31, 1498-1534. [CrossRef]

31. Forni, L.; Giordano, R. Employment in the Public Sector; Technical Report 1085, Working Paper; CESIFO: Munich, Germany, 2003.

32. Blanchflower, D.; Machin, S. Product Market Competition Wages and Productivity: International Evidence from EstablishmentLevel Data. Ann. Econ. Stat. 1996, 41/42, 219-253. [CrossRef]

33. Chatterjee, S.; Eyigungor, B. Maturity, Indebtedness, and Default Risk. Am. Econ. Rev. 2012, 102, 2674-2699. [CrossRef]

34. Mas, M.; Pérez-García, F.; Uriel, E. El Stock y los Servicios de Capital en España y su Distribución Territorial y Sectorial (1964-2010); Technical Report 2012109, Working Papers; Fundacion BBVA: San Luis, Mexico, 2012. 
35. Chamley, C.; Pinto, B. Why official Bail-Outs tend not to work: An example motivated by Greece 2010. Econ. Voice 2011, 8, 1-5.

36. Arellano, C.; Conesa, J.; Kehoe, T. Chronic Sovereign Debt Crisis in the Eurozone, 2010-2012; Technical Report 12-4, Economic Policy Paper; Federal Reserve Bank of Minneapolis: Minneapolis, MN, USA, 2012. 
37. Alesina, A.; Ardagna, S. Large Changes in Fiscal Policy: Taxes versus Spending. Tax Policy Econ. 2010, 24, 35-68. [CrossRef]

38. Aldrich, E.; Fernández-Villaverde, J.; Gallant, A.R.; Rubio-Ramírez, J.F. Tapping the supercomputer under your desk: Solving dynamic equilibrium models with graphics processors. J. Econ. Dyn. Control 2011, 35, 386-393. [CrossRef] 